\title{
GLOCALISATION AND READINESS FOR OPEN INNOVATION: THE ROLE OF INSTITUTIONAL SUPPORT IN TRANSITIONAL ECONOMIES
}

\author{
Bašić, M.
}

Maja Bašić / University of Zagreb, Faculty of Economics and Business, Department of International Economics, J.F. Kennedy Square 6, Zagreb, Croatia. E-mail: mbasic1@net.efzg.hr

\begin{abstract}
Studies on institutional support for the internationalisation of firms from transitional economies are inconclusive. This research contributes to the studies of institutional support in cases of firms with complementary innovation - internationalisation strategies. Mixed method research is used to support quantitative structural modelling. It uses qualitative interview data in combination with quantitative data gathered by a survey questionnaire on a sample of 88 telecommunications firms from the Croatia economy the year after it joined the European Union (2014). SmartPLS model is used to analyse data obtained through a questionnaire survey. The results show that institutions can assist firms in recombining their processes when they offer concrete product development support and, to a lesser extent, marketing support. The recombination of firms' processes, i.e. its ability to openly innovate, leads to significantly better globalised-localised (glocal) financial and marketing performance, which results are robust. The results are inconclusive in the case of glocal growth performance. The structural model assessed the effect of readiness for open innovation on glocal growth as positive and insignificant, while the robustness check found it to be positive and significant.

Implications for Central European audience: The value of this study is twofold. Firstly, it provides support and direction according to which institutional support could be directed to strengthen the internationalisation effort of the incumbent industry from transitional Central European economy that has transformed from the socialist to a market economy and undergone a process of joining the European Union. Secondly, it shows managers weak spots in institutional support and enables them to mitigate them quicker by finding similar support either outside of the firm on international markets or by employing highly qualified individuals.
\end{abstract}

Keywords: institutional support; open innovation; globalisation-localisation; telecommunications; transitional economies

JEL Classification: O30, P20, P33 


\section{Introduction}

Firms located in regions with well-developed institutional environments achieve high internationalisation levels (Xiao et al., 2019). Internationalisation results from firms' external and internal environments that work jointly to achieve their global and local competitive advantage (Denicolai et al., 2014). However, for firms from transitional economies achieving a competitive advantage in the international environment can be challenging due to obsolete technology and changing institutions, which presents a research problem this paper attempts to explain.

The Republic of Croatia is a Central European transition economy, which underwent a change from a socialist to a market-based system in the early 1990s, experienced an Independence War and changing institutions, and subsequently accessed into the European Union in July 2013. Accession into the European Union was intertwined with the rising expectation of European structural funds, regardless of the fact that less than twenty per cent of European SMEs are aware of institutional support initiatives, especially for internationalisation, and less than thirty per cent of internationalised SMEs introduced domestically new products or services (EC, 2010; Kalinic \& Clegg, 2017). Moreover, European SMEs mainly internationalise to other European union member states; hence, globalisation - localisation debate. The question emerges whether innovation and internationalisation are substitutive or complementary strategies for firms from transition economies (Kyläheiko et al., 2011) and whether institutional support is complementary with innovation - internationalisation strategies which this study addresses (Chen et al., 2018). Hence, the research question of this paper follows from the research problem and the abovementioned arguments:

$\mathbf{R Q}$ : What is the role of institutional support for firms with complementary innovation internationalisation strategies?

This paper is organised as follows. The theory and hypotheses development section comprises a theoretical foundation and illustrates the conceptual model of the study. The following section presents methodology with the explanation of data used in the study, measures, addressing a common method bias and adds a qualitative interview used to provide a rationale for the study. Results of the study with corresponding robustness checks are presented after the methodology section. The last section concludes the study with the main findings, managerial implications and limitations of the research.

\section{Theory and hypotheses development}

Nelson and Nelson (2002) argue that evolutionary economists see 'institutions' as moulding the technologies used by society and technological change itself. However, the effect of institutions on firm behaviour is still inconclusive. This is partly due to a vague concept of institutions as well as innovation processes with which they tend to be associated (Edquist \& Johnson, 2000). Within the neoclassical economic theory that centres on utility, individuals and profit maximisation, markets, and property rights act as institutions but are also associated with transaction costs. Nonetheless, as innovation is characterised by technological trajectories characteristic of a learning process, innovation-driven strategy (Chen et al., 2018) links innovation to internationalisation (Bryl, 2020). Namely, the export- 
led learning process can be used to combine the two approaches and consider them complementary.

If globalisation is associated with intertwining ideas, information and practices and offers alternative institutions, as is the case of transition of former socialist economies, it enables the diffusion of innovation (Mikl-Horke, 2004), which in turn should incite firm competitiveness and economic growth (Tomizawa et al., 2020). Bloom et al. (2019) summarise the pros and cons of different policy instruments for promoting innovation based on the premise that market economies are likely to underprovided innovation because of the good public nature of knowledge. They find that in the short run, R\&D tax credits and direct public funding have a positive effect on firm growth. On the other hand, there are strong intellectual property rights that oppose that argument. Hence, Figure 1 presents a conceptual foundation of this study.

Figure 1 | Conceptual framework

Environmental level

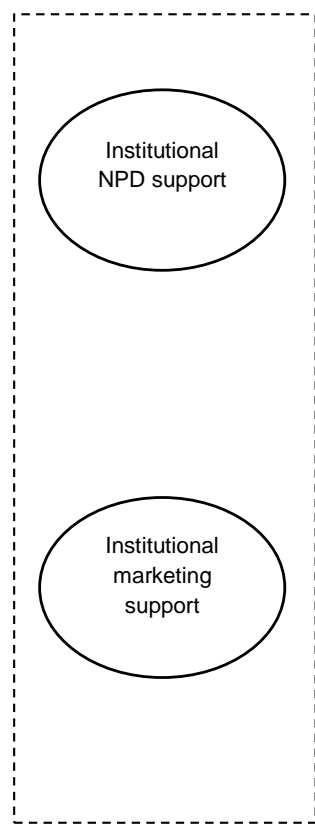

Firm level

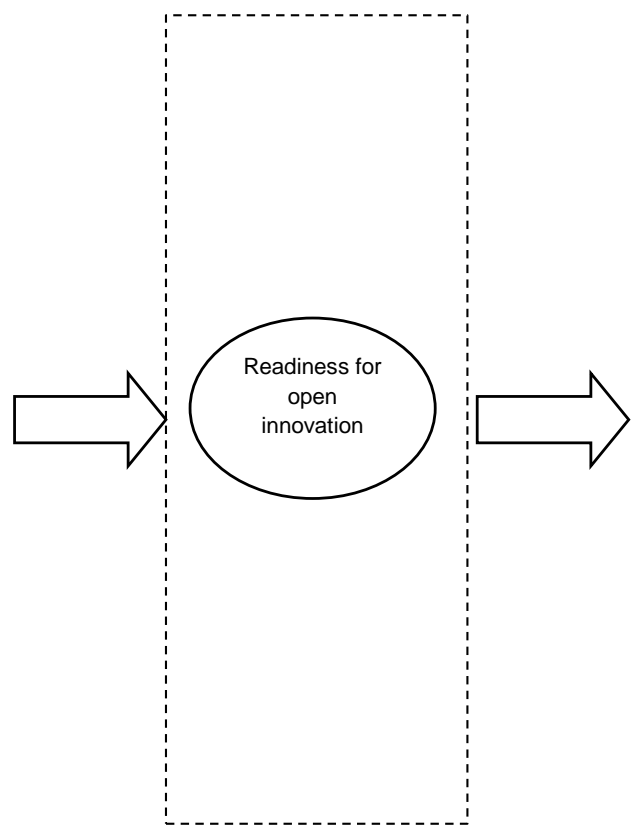

Glocalisation

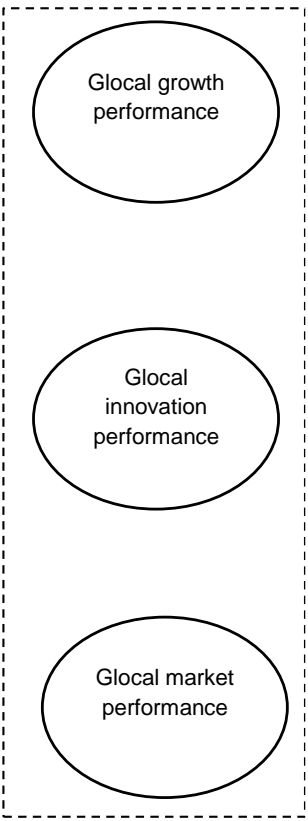

Source: author's own elaboration

Furthermore, this study inserts the concept of open innovation in the form of firms' readiness to openly innovate. The concept of open innovation gained legitimacy as product life cycles and lower costs and the time of product and service development shortened due to the lack of access to the technologies and high risk of innovating in isolation (Dahlander \& Gann, 2010). It depicts changes in working conditions (the majority of people do not have a lifetime job; hence, a new talent approach is required), job divisions that allow the trade of ideas through market institutions (intellectual property rights, venture capital, technological standards), and new technologies that induce new cooperation and 
coordination methods in multiple geographic areas (Dahlander \& Gann, 2010). If a firm lacks the competence to adapt to external changes, access information and appropriate risk, it can use open innovation as an alternative path to market (Mortara \& Minshall, 2011). By using alternative paths to market, firms can become more effective in their utilisation of internal and external resources, bring a higher quality of products onto the market and reduce the delays in the supply and value chains (Chesbrough, 2004, 2006) as they discover and use information, technology and knowledge that is widely dispersed and increase its competitiveness by acquiring information, technology, and knowledge at lower costs than it would take for a firm to develop itself (Chesbrough, 2011).

Although innovation is always open to a certain extent and open innovation is not a new phenomenon (Chesbrough, 2006; Dahlander \& Gann, 2010; West et al., 2014), open innovation processes should complement and sometimes substitute closed innovation modes (Lakhani et al., 2013). Firms can open their 'inter-organisational networks, organisational structures, evaluation processes and knowledge management systems to external processes (Chiaroni et al., 2010, p. 40). In this paper, Chesbrough's (2006, p. 1) definition of open innovation is used, whereby 'Open innovation is the use of purposive inflows and outflows of knowledge to accelerate internal innovation, and expand the markets for external use of innovation, respectively. [This paradigm] assumes that firms can and should use external ideas as well as internal ideas, and internal and external paths to market, as they look to advance their technology.'

With respect to constantly changing institutions in the transition economy, especially one that is faced with obsolete technology and a competitive market environment, this paper takes on the perspective of an open innovation model that a firm can use to re-design its processes to accommodate them to changing institutional and market conditions and in order to answer the research question: 'What is the role of institutional support for firms with complementary innovation - internationalisation strategies?'

\subsection{Institutional support and readiness for open innovation}

Support for firms seeking to internationalise is an important institutional policy challenge. The market, as well as technological knowledge, is often obtained through direct experience and vicarious learning (Zakery \& Saremi, 2020). Balanced policy support for firm internationalisation considers the diversity of firms and their capability to adapt and learn in new environments (Wright et al., 2007; Agostino et al., 2020).

Although studies are inconclusive on the effect of the institutional environment of transitional economies on firms' innovation capability (e.g. Adel et al. (2020) found adverse effects between the two), property rights are an important part of developed national institutions which influence economic development through propensity to innovate (Baklanova et al., 2020). There also exist five key institution-based barriers to innovation: (1) competition fairness, (2) access to financing, (3) laws and regulations, (4) tax burden, and (5) support systems (Zhu et al., 2012). When examining innovation subsidies from a municipality and government, collaboration with other firms and organisations, links with universities or research institutes and market scope, Radas and Bozić (2009) found that those institutional obstacles do not imply firms will innovate less, but that they will find a way around the obstacles depending on firm's domestic or international market scope. If internationalisation is market seeking, firms face similar barriers in terms of financial and capacity problems 
(Svetličič et al., 2007). Therefore, a question arises about the possible institutional assistance for firms striving to overcome international barriers by differing between product development and marketing support.

H1a: Institutional new product development support has a positive effect on the readiness for open innovation.

H1b: Institutional marketing support has a positive effect on the readiness for open innovation.

\subsection{Readiness for open innovation and internationalisation}

This study adopts the notion that internationalisation and innovation present complementary strategies for growth. Both are connected with uncertainty, asset specificity, appropriability of knowledge assets in addition to tacitness and economies of scale and scope (Saarenketo et al., 2008). Moreover, recombination of marketing and product innovation with innovation culture could exemplify a model for transitional economies (Aksoy, 2017). However, this could imply only the commercialisation of existing products (Stojčić, 2021).

In the context of Slovenian companies, Rangus et al. (2017) show that an organisation's capacity for open innovation can be used to its full potential in order to impact a firm's performance. Stojčić's (2021) findings confirm these results in the aspect of both radical and incremental innovations of Central and Eastern European economies. Additionally, in the context of transitional economies, Bahl et al. (2021) find that internationalisation can be negatively associated with innovation. This can be due to the lack of resources or, as they claim, knowledge-based capabilities found in absorptive capacity, appropriation capability, and managerial capability that positively moderate the negative innovationinternationalisation relationship. Miočević and Crnjak-Karanović (2010) suggest that a significant relationship between global mindset and internationalisation exists through the managerial perception of effective marketing activity, while Fong-Reynoso and OcampoFigueroa (2010) stress the significance of experience and relational capital. A similar notion was confirmed by Vuković et al. (2018) in the case of the Serbian hotel industry. These studies confirm the importance of organisational change (Radas \& Božić, 2009). Hence, the second hypothesis:

H2a: A firm that is ready for open innovation has a faster glocal growth.

H2b: A firm that is ready for open innovation has a better glocal innovation performance.

H2c: A firm that is ready for open innovation has a better glocal market performance.

\section{Methodology}

\subsection{Research context: Telecommunications industry}

Telecommunication development is complex and comprises multiple technologies used to cover both product and service sectors (Huurdeman, 2003). It is composed of both manufacturing and services whose radical innovations pertain to domestic markets (Bašić et al., 2018). Over history, it has been naturally attributed as a monopoly whose technical integration into international systems served as a prerequisite for its development (for telephone services, see Noam, 1992). Today it operates in oligopolistic markets (Bašić et al., 2020; Erramilli, 1990; Grönroos, 1999; Roy \& Yami, 2009) with only a portion of truly global 
firms (e.g. Ericsson or Deutsche Telekom; see Curwen \& Whalley, 2007). However, telecommunications firms' monopolistic power aims to be limited due to their power and scope of influence. Telecom's complex internal processes make it difficult to follow omnichannel strategy due to historical development and service portfolio (Fabel et al., 2018). As telecoms depend on retail channels, their key challenges nowadays encompass a transition to digital channels and an appropriate omnichannel mix in line with productivity, service quality growth and return on investments in line with an increase in partner channels for distribution of telecommunications products and services. Therefore, as Laffont and Tirole (2001) note, telecommunications have been at the forefront of the regulation reform, whose competition developed faster than in other industries.

Croatia's telecommunications industry development after the 1991 Independence war and transition to an open market economy has been exceptionally fast (Brlić et al., 2000). Sabolić's (2009) study shows that Croatia's regulatory system might not be ready for effective market power regulation compared to the rest of the European Union countries. Nefat et al. (2012) confirmed the importance of service recovery based on customers' satisfaction in Croatian mobile telecommunications. Hence it is the aim of this study to inspect the role of institutional support for telecommunication firms' open innovation challenges and how they transform into effective glocal competitiveness.

\subsection{Sample and data collection}

The sample for the study was drawn from the pool of Croatian telecommunications companies. Focus on the Croatian telecommunications industry is a response to calls for further studies linked to transition economies and based on improving our understanding of the impact of institutions and firms' performance (Peng \& Luo, 2000; Nyuur et al., 2016).

Firms in the sample (with names and contact details of owners/managers) were identified through a database of the official Croatian Finance agency known as 'Croatian Registrar of the publicly available financial data' and Orbis database in 2013. Researchers used the database to identify a total of 347 telecommunications firms operating in Croatia. 334 of them were small and medium-sized firms. The statistical classification used was NACE statistical classifications 26.3 and 26.4. All the companies in the population of the identified telecommunications firms were contacted. The decision assumed that a very conservative response rate of 10 per cent in Croatia would produce a return of approximately 34 replies.

The study used a survey design that underwent a rigorous three pre-tests procedure and used pre-existing measures where possible (Coviello et al., 2000; Peng \& Luo, 2000; Sheng et al., 2011). Confidentiality was ensured to encourage participants to be candid in their responses. Two reminders of the surveys were sent, and additional managers who could not be contacted over e-mail or telephone were identified and contacted over the professional social network Linkedin. It allowed identification of CEOs of smaller firms or their respective Heads of Production, Marketing or Sales.

Data collection took place from the beginning of March until the end of May 2014. A total of 128 questionnaires were returned, 18 firms comprised multiple responses. After the ambiguous data were eliminated, the analysis counted the total of 88 firms in the sample, amounting to a 25.36 per cent response rate. A sample of this size is considered appropriate for the purpose of this study. Quantitative data gathered through primary research used 
structural equation modelling by using correlation and partial least squares path modelling technique as suggested by Hair et al. (2018). SmartPLS software was used for that purpose.

\subsection{Common methods bias}

Common method bias results from a measurement error in an instrument that might lead to the erroneous conclusions (Chang et al., 2010). Harman's single factor tests the latent variables for the possible noises in the research instrument. The presence of a substantial amount of common method bias occurs when one factor explains more than $50 \%$ of the dependent variable's variance (Podsakoff \& Organ, 1986; Huang et al., 2010). Harman's single factor was tested on all 13 items by constraining the number of factors to 1 . The total variance extracted was $39.05 \%$, implying that the single factor explained for $39.05 \%$ of the variance. As this is less than $50 \%$ of the variance explained by the single factor, the common method bias is not an issue in this analysis.

On the other hand, the factor loading of 13 variables extracted a three-factor solution by using a varimax orthogonal rotation. However, in the subsequent structural equation analysis, we differentiated between several latent variables to sample an adequate discriminant validity.

\subsection{Qualitative research}

Several interviews were conducted to support a survey as a research instrument and gain qualitative support for our quantitative research. As Eisenhardt (1989) points out, there is an additional value to the research when qualitative research is involved. Herein one qualitative interview is presented to obtain support for our model and to depict significant constructs for the quantitative study (Yin, 1984). Presenting additional interviews would be a topic for another research and would demand a different approach. For that purpose, an interview with the technical project manager from the largest Croatian telecommunications exporting company took place on 13 April 2014.

Our respondent was male, with eight years of work experience employed on information systems projects that are not bound by location, i.e., geographical area of one country. Respondent's job deals with service improvement and implementation of new services, mainly in the business-to-business sector of the largest Croatian telecommunication firm. His firm offers solutions in the form of leasing/renting servers, leasing/renting applications, leasing/renting CRM, ERM, data storage warehouses, virtual computers, wherein human resources, legal requirements, and is not part of any cluster, but it is a private company under foreign ownership.

Market research in a company is performed by the marketing and operations departments. Its forms include, e.g. users who indicate a particular need for a service or for function in service. When the company notes similar requests by several users, it moves on to develop the service. Firstly, a business plan is made to see whether it is profitable to develop this service, how much are the development costs, and what is the expected revenue of this service. Then, these demands are being categorised, which are then being taken into consideration in terms of resources and which are subsequently going to be implemented. Regardless of that, the marketing department regularly and daily, through the various agencies and internally, does the market research and inspects the needs for new services. In this company, market research is more valuable than if the technical employees express the wish to implement something or suggest doing the same. If a technical employee 
suggests, market research will be done by the marketing department in order to see whether this idea is viable and could it be profitable or not.

Only in the technical department there are nine main organisations in the company, and each organisation has, depending on each organisation, 5 to 10 business units making the communication between departments and prioritising is extremely important. Employees in these units are mainly tertiary-educated economists/business studies graduates or ICT engineers, depending on the segment they are working in. New projects are developed and being thought about on a daily basis, mentioning that these technologies might not be new globally, but it is new in the region of former Yugoslavian countries. The vision of cooperation is shared throughout the company but also through external vendors if the project might take a shorter time to be executed by a vendor company. Each year 'initiatives' are planned for the subsequent year multiplying and spreading down through a hierarchical chain. Although referrals are made for vendors and penalties in contracts exist, the main barriers in project implementation occur with vendors, which prolongs project implementation time and serves not only as a bad reputation but as general disagreements. Also, the noticed issue is innovation performance measurement. Regardless of the market and technical research, projects occur where the company spends a lot of money with a little return. However, no one is to blame for that issue. Although, post-sales process and measures that determine how much the company invested, how much it earned, for $x$ number of months we will earn $y$ amount of money. There becomes an issue: who has made these suggestions anyway. In terms of the internationalisation of new product or service development, the practices of the whole group apply. If a particular service is launched in Poland, all members of the group will apply for a similar service. On the other side, if Croatian teams implement a good project in Croatia, it will be expanded to other members of the group. Hence, each country is looked at as an entity, and a group is looked at as a whole. Of course, for this size of a group, there exists inertia in and between particular departments that sometimes diminishes the speed of project implementation.

In terms of a government role, our respondent suggests that it should help regarding research on new technologies to cooperate with other countries on, e.g. foreign suppliers, for a government to receive better deals for their customer base in Croatia. Also, market research and investment-wise.

In terms of comparison with competitors, our respondent states that a company is better than competitors in everything apart from the price. And the reason is due to regulators. Namely, there are other companies in the market in which the regulatory agency stated that we could not sharply decrease prices because the competitors need to find their place in the market. Hence, our company obtained a timeframe in which it is allowed to lower the prices, making its products/services more expensive in the short run. Although in Croatia and the region, a company has large market shares. The most important thing is that the company is the owner of the majority of telecommunication infrastructure in Croatia. This is really important because, at one point or another, it comes down to this. For example, if you as a user chose another service provider at one point, a customer will come back to them eventually. 


\subsection{Measures}

\section{Control variables}

The validity of the study is strengthened by controlling the variables in the model: the type of ownership and firm size.

Private ownership. Private ownership was controlled because some firms in the Croatian telecommunications industry are partly in government ownership and might be more prone to the inertia of the business model that influences their glocalisation performance (Nyuur et al., 2016). Namely, in transition economies for both private and public companies, improved performance might come from social-political and business ties, especially if in the case of a public state-owned company (Xin \& Pearce, 1996). Private ownership was measured with a dummy variable, coded 0 for private firms and 1 for state-owned firms.

Firm size. We controlled for the firm size as greater firm size can imply the greater ability of a firm to manage supplier and customer relationships, hence, be readier to adapt to changing market conditions, and simultaneously imply better glocalisation performance (Coviello et al., 2000; Peng \& Luo, 2000). Firm size was measured with a firm's average annual turnover for the period between 2010 and 2013. Firms were grouped according to their turnover based on the Croatian statistical classification of firm size, which is consistent with the Eurostat firm size definition: micro-companies less than 2 million EUR turnover (equivalent to 15 million HRK), small companies less than 10 million EUR turnover (equivalent to 75 million HRK), medium-sized companies less than 50 million EUR turnover (about 350 million HRK), and large companies more than 50 million EUR turnover.

Table 1 shows the characteristics of the firms in the sample. There are seven state-owned firms in the sample.

Table 1 | Characteristics of the sample

\begin{tabular}{lcc}
\hline Characteristic & Frequency & $\%$ \\
\hline Ownership & 7 & \\
\hline Private & 26 & $8.54 \%$ \\
\hline $\begin{array}{l}\text { Firm size } \\
\text { (Average annual turnover for the period between 2010 and 2013) }\end{array}$ & \\
\hline 0-5 million HRK & 11 & $31.7 \%$ \\
$5-15$ million HRK & 16 & $13.4 \%$ \\
15-75 million HRK & 16 & $19.5 \%$ \\
$75-350$ million HRK & 13 & $19.5 \%$ \\
more than 350 million HRK & & $15.8 \%$ \\
\hline & & \\
\hline Internationalisation age & 0 & $0.0 \%$ \\
\hline Before 1950s & 2 & $2.4 \%$
\end{tabular}




\begin{tabular}{lcc}
$1981-1995$ & 4 & $4.9 \%$ \\
$1996-2000$ & 13 & $15.9 \%$ \\
$2001-2005$ & 16 & $19.5 \%$ \\
$2006-2010$ & 28 & $34.1 \%$ \\
After 2010 & 19 & $23.2 \%$ \\
\hline Number of foreign markets & 11 & \\
\hline 0 & 11 & $13.4 \%$ \\
1 & 14 & $13.4 \%$ \\
2 & 10 & $17.1 \%$ \\
3 & 2 & $12.2 \%$ \\
4 & 6 & $2.4 \%$ \\
5 & 28 & $7.3 \%$ \\
\hline
\end{tabular}

Source: author's own calculations

$31.7 \%$ of companies have had an average annual turnover of less than 5 million HRK, $32.9 \%$ between 5 and 75 million HRK, and $32.2 \%$ had an average annual turnover greater than 75 million HRK. The majority of firms (92.7\%) internationalised after the Croatian Independence war, i.e., after 1995 . Also, $13.4 \%$ of firms are based purely on the domestic market, $30.5 \%$ cover 1 or 2 international markets, while the rest of firms operate on three or more international markets.

\section{Dependent variables}

The dependent variable was measured using a 7-item scale which was adopted from the works of De Luca and Atuahene-Gima (2007), Langerak et al. (2004), and Doblinger et al. (2013). Respondents depicted on a 7-point Likert scale how good, compared to their firm's closest international competitors, is their performance according to the given indicators (1 worse than competitors, 7 - much better than competitors). Three constructs were subsequently identified: (1) glocal growth performance, (2) glocal innovation performance, (3) glocal market performance. Table 2 portrays information on items in the constructs. The validity of the study is strengthened by controlling the variables in the model: the type of ownership and firm size.

\section{Independent variables}

Institutional support was measured with 5-item scale developed by Busenitz, Gomez and Spencer (2000) and adopted for the purpose of this study. Two constructs are depicted: (1) institutional marketing support and (2) institutional new product development support (see Table 2 for details). 
Readiness of a business model for open innovation was adopted from Huang et al. (2013), Sisodiya et al. (2013), Johnson et al. (2008), Moore (2004), Parida et al. (2012), and Hung and Chou (2013). The construct finally contains only two items for the purpose of this study, namely firms' readiness to re-design customers value propositions and firms' readiness to redesign business processes, as exemplified in Table 2.

Construct validity and reliability

Table 2 shows descriptive statistics, measurement model and convergence validity with factor loadings. All factor loadings of principal factor analysis are greater than 0.8 , Cronbach alpha is greater than 0.7 , composite reliability is about 0.9 or higher and average variance extracted is greater than 0.7 . Hence, the measurement model is adequate.

Table 2 | Descriptive statistics. Measurement model: Convergence validity

\begin{tabular}{lcccccc}
\hline & $\begin{array}{c}\text { Factor } \\
\text { loadings }\end{array}$ & $\mathrm{N}$ & Min & Max & Mean & S.D. \\
\hline Glocalisation &
\end{tabular}

calisation

(Adopted from De Luca \& Atuahene-Gima, 2007; Doblinger et al., 2013; Langerak et al., 2004)

Please estimate for the past four years (2010, 2011, 2012 and 2013).

How good, compared to your closest international competitors, is your performance in the following areas?

\section{Glocal innovation performance}

(Cronbach's alpha $=0.78 ; \mathrm{CR}=0.90 ; \mathrm{AVE}=0.82$ )

\begin{tabular}{lllllll}
\hline $\begin{array}{l}\text { 1. Rate of new products, services } \\
\text { or processes' success }\end{array}$ & 0.90 & 82 & 1 & 7 & 3.99 & 1.39 \\
2. Time to break-even & 0.91 & 82 & 1 & 7 & 3.85 & 1.50 \\
\hline
\end{tabular}

\section{Glocal performance}

(Cronbach's alpha $=0.86 ; \mathrm{CR}=0.92 ; \mathrm{AVE}=0.78$ )

\begin{tabular}{lllllll} 
3. Total market share & 0.94 & 82 & 1 & 7 & 3.55 & 1.58 \\
$\begin{array}{l}\text { 4. Number of identified new } \\
\text { markets and opportunities }\end{array}$ & 0.91 & 82 & 1 & 7 & 3.77 & 1.46 \\
\begin{tabular}{l} 
5. Total sales revenue \\
\hline
\end{tabular} & 0.80 & 82 & 1 & 7 & 3.65 & 1.54 \\
\hline
\end{tabular}

\section{Glocal growth performance}

(Cronbach's alpha $=0.79 ; \mathrm{CR}=0.89 ; \mathrm{AVE}=0.81$ )

\begin{tabular}{lllllll} 
6. Growth of the sales revenue & 0.97 & 82 & 1 & 7 & 4.06 & 1.35 \\
7. Growth of the market share & 0.83 & 82 & 1 & 7 & 3.95 & 1.44 \\
\hline
\end{tabular}

\section{Institutional support}

(Adopted from Busenitz et al., 2000)

To what extent do government agencies' support your industry's product, service or process development?

Government agencies: 


\begin{tabular}{|c|c|c|c|c|c|c|}
\hline $\begin{array}{l}\text { Institutional NPD support } \\
\text { (Adopted from Oviatt \& McDougall's } \\
0.98 ; \text { AVE }=0.96\end{array}$ & 55; Zar & 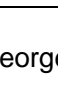 & & & & \\
\hline 1.sponsor organisations which help & & & & & & \\
\hline $\begin{array}{l}\text { to identify potential collaborators in } \\
\text { designing new products, services }\end{array}$ & 0.98 & 82 & 1 & 6 & 1.84 & 1.24 \\
\hline $\begin{array}{l}\text { 2. have special projects for } \\
\text { organisations wishing to develop a } \\
\text { new product, service or process. }\end{array}$ & 0.98 & 82 & 1 & 6 & 2.13 & 1.36 \\
\hline Institutional marketing support & & & & & & \\
\hline Cronbach's alpha $=0.82 ; \mathrm{CR}=0.92$ & $E=0 . \varepsilon$ & & & & & \\
\hline $\begin{array}{l}\text { 3. help in identifying potential } \\
\text { international markets for a new } \\
\text { product, service or process. }\end{array}$ & 0.92 & 82 & 1 & 7 & 1.94 & 1.16 \\
\hline $\begin{array}{l}\text { 4. help us find new market niches, } \\
\text { even when our organisation does } \\
\text { not do well. }\end{array}$ & 0.93 & 82 & 1 & 5 & 1.53 & 0.87 \\
\hline
\end{tabular}

\begin{tabular}{|c|c|c|c|c|c|c|}
\hline \multicolumn{7}{|c|}{$\begin{array}{l}\text { Readiness for open innovation } \\
\text { (Adopted from Huang et al., 2013; Hung \& Chou, 2013; Johnson et al., 2008; Moore, 2004; Parida et } \\
\text { al., 2012; Sisodiya et al., 2013) } \\
\text { Cronbach's alpha }=0.96 ; \mathrm{CR}=0.98 ; \text { AVE }=0.96 \\
\text { Please rate your organisation's readiness for open innovation. } \\
\text { Without negative effects on our core business, our processes and structures enable us to: }\end{array}$} \\
\hline $\begin{array}{l}\text { 1. re-design customers' value } \\
\text { propositions. }\end{array}$ & 0.98 & 82 & 1 & 7 & 4.75 & 1.36 \\
\hline $\begin{array}{l}\text { 2. develop a new business } \\
\text { process. }\end{array}$ & 0.98 & 82 & 1 & 7 & 4.91 & 1.44 \\
\hline \multicolumn{7}{|l|}{ Control variables } \\
\hline Ownership (private) & & 82 & 0 & 1 & 0.909 & 0.28 \\
\hline $\begin{array}{l}\text { Firm size (average annual } \\
\text { turnover) }\end{array}$ & & 82 & 1 & 5 & 2.70 & 1.46 \\
\hline
\end{tabular}

Source: author's own calculations

\section{Results}

This section depicts the results of the empirical analysis. Statistical software package SmartPLS was used for quantitative data analysis for structural equation modelling as a method of analysis. Correlation and partial least square structural equation modelling were used to test the two hypotheses. Six latent constructs containing reflexive items and a small sample size ( $\mathrm{N}=82)$ was the rationale for the analysis (Hair et al., 2018). 
Table 3 | Descriptive statistics. Measurement model: Convergence validity

\begin{tabular}{llcccccccc}
\hline & & $\mathbf{1}$ & $\mathbf{2}$ & $\mathbf{3}$ & $\mathbf{4}$ & $\mathbf{5}$ & $\mathbf{6}$ & $\mathbf{7}$ & $\mathbf{8}$ \\
\hline 1 & Glocal growth performance & $\mathbf{0 . 9 0}$ & & & & & & & \\
2 & Glocal innovation performance & 0.61 & $\mathbf{0 . 9 0}$ & & & & & \\
3 & Glocal market performance & 0.50 & 0.78 & $\mathbf{0 . 8 9}$ & & & & \\
4 & Institutional NPD support & 0.09 & 0.55 & 0.67 & $\mathbf{0 . 9 8}$ & & & \\
5 & Institutional marketing support & 0.30 & 0.68 & 0.47 & 0.39 & $\mathbf{0 . 9 9}$ & & \\
6 & Readiness for open innovation & 0.29 & 0.77 & 0.65 & 0.83 & 0.78 & $\mathbf{0 . 9 8}$ & \\
7 & Ownership & -0.11 & -0.11 & -0.10 & 0.06 & 0.07 & 0.08 & $\mathbf{1}$ \\
8 & Size & 0.30 & 0.67 & 0.74 & 0.53 & 0.51 & 0.54 & -0.04 & $\mathbf{1}$ \\
\hline
\end{tabular}

Note: bold diagonal figures are the square roots of average variance extracted.

Source: author's own calculations

Correlation coefficients are not higher than 0.7 apart from those between (1) readiness for open innovation and glocal innovation performance and (2) readiness for open innovation and institutional marketing support, indicating that multicollinearity is not a problem in this analysis. Hence, Table 4 presents the results of the Hypothesis 1 testing.

Table 4 | Structural model and path coefficients: Institutional support modes and readiness for open innovation

\begin{tabular}{lc} 
& $\beta$ \\
& $(\mathrm{S} . \mathrm{E})$. \\
\hline Independent variables & \\
$\quad$ Institutional NPD support & $0.62^{\star *}$ \\
& $(0.24)$ \\
\multicolumn{1}{c}{ Institutional marketing support } & $0.54 \dagger$ \\
f2 (Institutional NPD support) & $(0.28)$ \\
f2 (Institutional marketing support) & 5.23 \\
$R^{2}$ & 4.03 \\
Adjusted $R^{2}$ & 0.94 \\
Q2 & 0.94 \\
SRMR & 0.87 \\
& 0.07 \\
Chi-Square & $(0.21)$ \\
& 224.04 \\
NFI & $(301.72)$ \\
& 0.70 \\
& $(0.59)$
\end{tabular}

Note: S.E. $=$ standard error. $\mathrm{N}=88$. Two-tailed test. Unstandardized coefficients reported; $\uparrow p<0.10$; ${ }^{*} p<0.05 ;{ }^{* *} p<0.01 ;{ }^{* * *} p<0.001$.

Source: author's own calculations 
The results presented in Table 4 show the significant and positive effect of institutional new product development support on readiness for open innovation at 0.1 per cent level, and positive but insignificant effect of institutional marketing support on readiness for open innovation (however, it is significant at the 10 per cent level). Adjusted R2 is 0.94 , indicating that a high proportion of variance in the model is explained by the institutional new product development and institutional marketing support. Hence, we cannot reject hypothesis 1.

Table 5 presents the results of the structural model and path coefficients between readiness for open innovation and glocal performance.

Table 5 | Structural model and path coefficients: Readiness for open innovation and glocal performance

\begin{tabular}{|c|c|c|c|c|c|c|}
\hline & \multicolumn{2}{|c|}{$\begin{array}{l}\text { Glocal growth } \\
\text { performance }\end{array}$} & \multicolumn{2}{|c|}{$\begin{array}{l}\text { Glocal innovation } \\
\text { performance }\end{array}$} & \multicolumn{2}{|c|}{$\begin{array}{l}\text { Glocal market } \\
\text { performance }\end{array}$} \\
\hline & $\begin{array}{c}\text { Model } \\
1\end{array}$ & $\begin{array}{l}\text { Model } \\
2\end{array}$ & $\begin{array}{c}\text { Model } \\
1\end{array}$ & $\begin{array}{c}\text { Model } \\
2\end{array}$ & $\begin{array}{c}\text { Model } \\
1\end{array}$ & $\begin{array}{c}\text { Model } \\
2\end{array}$ \\
\hline & $\begin{array}{c}\hat{\beta} \\
(S . E .)\end{array}$ & $\begin{array}{c}\hat{\beta} \\
(\text { S.E. })\end{array}$ & $\begin{array}{c}\hat{\beta} \\
(S . E .)\end{array}$ & $\begin{array}{c}\hat{\beta} \\
(S . E .)\end{array}$ & $\begin{array}{c}\hat{\beta} \\
(S . E .)\end{array}$ & $\begin{array}{c}\hat{\beta} \\
\text { (S.E.) }\end{array}$ \\
\hline \multicolumn{7}{|l|}{ Control variables } \\
\hline Ownership & $\begin{array}{l}-0.11 \\
(0.14)\end{array}$ & $\begin{array}{l}-0.12 \\
(0.12)\end{array}$ & $\begin{array}{l}-0.09 \\
(0.08)\end{array}$ & $\begin{array}{l}-0.08 \\
(0.07)\end{array}$ & $\begin{array}{l}-0.07 \\
(0.09)\end{array}$ & $\begin{array}{l}-0.11 \\
(0.09)\end{array}$ \\
\hline Size & $\begin{array}{c}0.29 \\
(0.18)\end{array}$ & $\begin{array}{c}0.20 \\
(0.31)\end{array}$ & $\begin{array}{l}0.68^{* * *} \\
(0.13)\end{array}$ & $\begin{array}{c}0.24 \\
(0.21)\end{array}$ & $\begin{array}{l}0.74^{\star \star *} \\
(0.15)\end{array}$ & $\begin{array}{l}0.54^{\star *} \\
(0.17)\end{array}$ \\
\hline \multicolumn{7}{|l|}{$\begin{array}{l}\text { Independent } \\
\text { variable }\end{array}$} \\
\hline $\begin{array}{l}\text { Readiness for } \\
\text { open } \\
\text { innovation }\end{array}$ & & $\begin{array}{c}0.19 \\
(0.34)\end{array}$ & & $\begin{array}{c}0.83^{\star * *} \\
(0.22)\end{array}$ & & $\begin{array}{c}0.37^{*} \\
(0.17)\end{array}$ \\
\hline f2 (Ownership) & 0.01 & 0.02 & 0.02 & 0.03 & 0.01 & 0.03 \\
\hline f2 (Size) & 0.09 & 0.03 & 0.88 & 0.16 & 1.24 & 0.59 \\
\hline $\begin{array}{l}\text { f2 (Readiness for } \\
\text { open innovation) }\end{array}$ & & 0.03 & & 1.15 & & 0.28 \\
\hline$R^{2}$ & 0.10 & 0.13 & 0.47 & 0.75 & 0.56 & 0.65 \\
\hline Q2 & 0.04 & 0.00 & 0.33 & 0.48 & 0.38 & 0.46 \\
\hline
\end{tabular}

Note: S.E. = standard error. $\mathrm{N}=88$. Two-tailed test. Unstandardized coefficients reported; $\uparrow p<0.10$; ${ }^{*} p<0.05 ;{ }^{* *} p<0.01 ;{ }^{* * *} p<0.001$.

Source: author's own calculations

Model 1 in Table 5 presents the model with control variables, while Model 2 in Table 5 presents the model with control variables and the independent variable. Results indicate a positive and significant effect of readiness for open innovation on glocal innovation and market performance. Hence, hypotheses $2 b$ and $2 c$ cannot be rejected. On the other hand, there is an insignificant effect of readiness of open innovation on glocal growth performance, so hypothesis 2 a cannot be accepted. A summary of the model with resulting path coefficients and levels of significance is illustrated in Figure 2, and the summary of the tested hypotheses is presented in Table 6. 
Figure 2 | Structural model

Environmental level

Firm level

Glocalisation

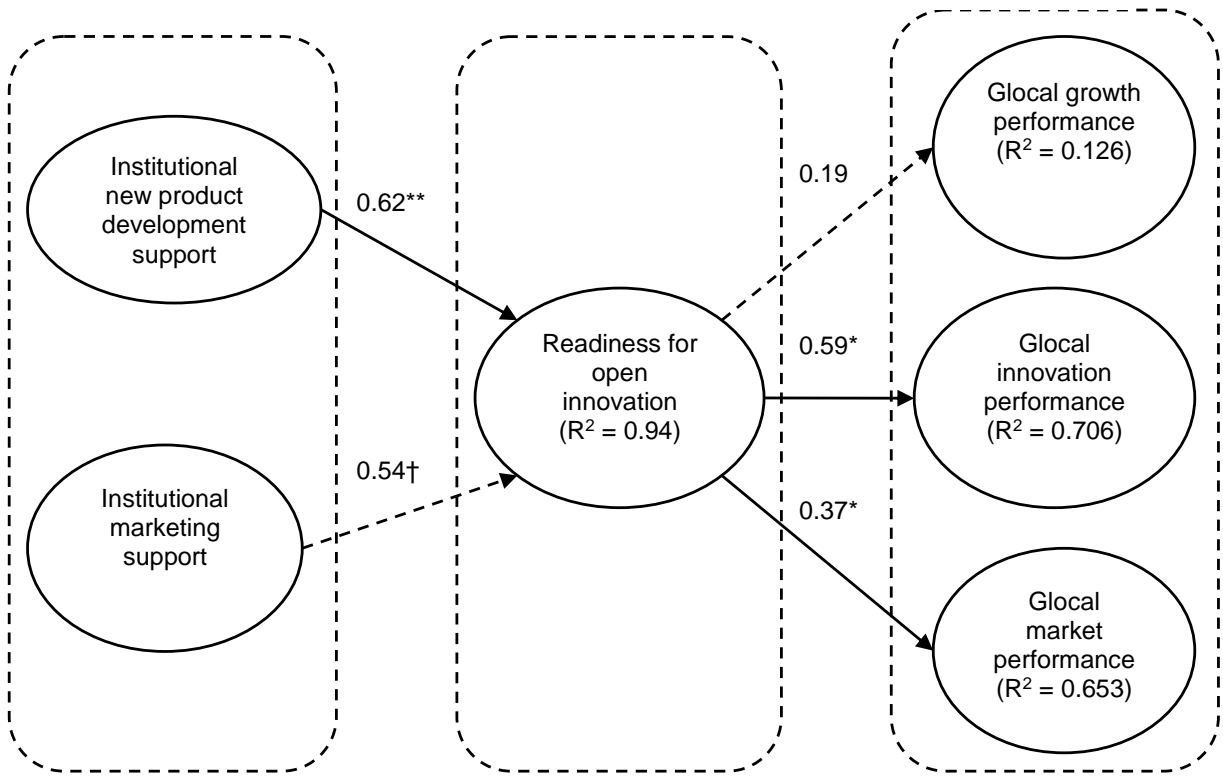

Note: $\dagger p<0.10 ;{ }^{*} p<0.05 ;{ }^{* *} p<0.01 ;{ }^{* * *} p<0.001$

Source: author's own elaboration

Table 6 | Summary of hypotheses tests

\begin{tabular}{cllc}
\hline & Paths & Expected & Empirical \\
& & sign & conclusion \\
\hline$H 1 a$ & Institutional NPD support $\rightarrow$ Readiness for open innovation & Positive & Supported \\
$H 1 b$ & Institutional marketing support $\rightarrow$ Readiness for open innovation & Positive & Not supported \\
H2a & Readiness for open innovation $\rightarrow$ Glocal growth performance & Positive & Not supported \\
H2b & Readiness for open innovation $\rightarrow$ Glocal innovation performance & Positive & Supported \\
H2c & Readiness for open innovation $\rightarrow$ Glocal market performance & Positive & Supported
\end{tabular}

Source: author's own elaboration

Robustness check

Amadeus Buro van Dijk database was used to extract seven information and telecommunications companies based on the NACE2 main revision (subset $\mathrm{J}$ ) of industries in the largest 300 Croatian exporters based on their export revenue in the period 2006-2015. To check for validities and consistency of our cross-sectional analysis, a panel data analysis with fixed effects was used. Unfortunately, the database offers only financial and some descriptive microdata, so a panel fixed effects model was used to assess the effect of the level of intangible assets, as a proxy for readiness for open innovation, on sales and market 
share, as proxies for glocal performance and glocal growth performance. Interestingly the increase in intangible fixed assets has a significant positive effect both on sales and on market share. Additionally, an increase in intangible fixed assets have a significant positive effect on the growth of sales but not on the growth of market share. Additionally, we tested the effect of the level of intangible assets and their increase on exports and export growth and found a positive and significant relationship at a $1 \%$ significance level.

\section{Discussion and conclusion}

This study attempts to explain the research problem that concerns firms from transitional economies that attempt to achieve competitiveness in the international environment while being challenged with obsolete technology and changing institutions. Subsequently, to tap into this research problem, this study posed a research question: 'What is the role of institutional support for firms with complementary innovation - internationalisation strategies?'

The findings from this study confirm that institutional support is a significant positive factor contributing to firms with a lack of internal resources to achieve innovation internationalisation link. In this study, innovation and internationalisation are viewed as complementary strategies. Furthermore, the results show that the firm ability to recombine its existing processes quickly affects its competitive glocal market and financial performance but does not yet affect its glocal growth. The reason for this could come from the transition of companies from socialist to a capitalist market system where adjustment to a fast-changing business environment is a prerequisite for growth, which incumbent companies have not yet been able to overcome.

Firms need to be able to establish abroad to learn how to compete effectively on the same terms as their peers. Innovation - internationalisation link is crucial in this respect, as well as institutional support for firms from transitional markets competing in the developed market. This is the case of Croatian firms which compete with the developed member states of the European union's firm after Croatia's accession into the European Union in 2013. The question for policymakers is how best to design policy such that firms lacking knowledge about international markets or requiring assistance in terms of product or service development receive that support faster, not merely from the government but that government serves as a linkage connecting various business sectors. Although some research shows that institutional support is often unnoticed, firms nowadays are required to compete in a fast-changing environment. Hence, the lack of visibility should be a problem for policymakers to address. Considering the Republic of Croatia, which is now a part of the European Union, according to whose research more than 70 per cent of small and mediumsized firms do not nor wish to export, they would benefit from a holistic approach to innovation (Chen et al., 2018). In the framework of this study, assistance in finding marketing niches or product development support by connecting firms with universities or institutes would make a good addition to their limited resources and enable non-financial support. Hence, building on the institutional and international business literature, this study has several theoretical and managerial implications. 


\section{Theoretical implications}

The paper contributes to open innovation and internationalisation literature and provides insights into how the practitioners can use an appropriate institutional setting to maximise success in the open innovation paradigm. Based on the support of institutions, research of which was inconclusive, this study confirmed the importance of positive institutional support for new product development and slightly less for market development. Hence, institutions assist firms with limited resources, especially nowadays, when the strive is towards a transparent society that is encompassed in a holistic innovation approach.

Readiness for open innovation a concept that is nowadays irreplaceable and relates to firms' absorptive capacity and dynamic capabilities. Namely, their ability to recombine existing knowledge with external knowledge is extremely important. Not only that it affects firms current market position, but it also affects firms international and local, i.e. glocal innovation performance. This finding is especially relevant as there are only limited studies on open innovation in transitional economies, and the majority of studies aim for developed economies where there is the availability of data.

\section{Managerial implications}

There are several managerial implications. First, the level of impact each of the institutional support has on readiness is different. The results show that firms can rely on institutional product development support. Hence, this is a valuable finding. On the other hand, marketing support should be strived to be found elsewhere as there seem to be better experts outside the institutionalised arena.

\section{Limitations and future research}

The limitations of this study are several. As previously mentioned, this study used a crosssectional research design and a relatively small sample size coming from one country. These limitations can affect the generalisability of the findings only to a sector of telecommunications. Although the attempt was to include both manufacturing and service sectors of the telecommunications industry, future studies might consider a longitudinal approach comprising different industries. Similarly, it would be beneficial to re-examine the effect of institutional financing and political ties as well as institutional quality on innovation internationalisation link.

Additionally, the borrowed scale that is used in previous research was applied in different institutional settings, e.g. the USA. Although these items have been subjected to validity and reliability tests, they have not been subjected to rigorous psychometric testing. Hence, to ensure discriminant validity, only a few items are loaded on each construct. Finally, it would be beneficial to examine absorptive capacity in more detail to obtain more consistent estimates and results.

\section{References}

Adel, H. M., Mahrous, A. A., \& Hammad, R. (2020). Entrepreneurial marketing strategy, institutional environment, and business performance of SMEs in Egypt. Journal of Entrepreneurship in Emerging Economies, 12(5), 727-746. https://doi.org/10.1108/JEEE-11-2019-0171 
Agostino, M., Di Tommaso, M. R., Nifo, A., Rubini, L., \& Trivieri, F. (2020). Institutional quality and firms' productivity in European regions. Regional Studies, 54(9), 1275-1288. https://doi.org/10.1080/00343404.2020.1712689

Aksoy, H. (2017). How do innovation culture, marketing innovation and product innovation affect the market performance of small and medium-sized enterprises (SMEs)? Technology in Society, 51(4), 133-141. https://doi.org/10.1016/j.techsoc.2017.08.005

Bahl, M., Lahiri, S., \& Mukherjee, D. (2021). Managing internationalisation and innovation tradeoffs in entrepreneurial firms: Evidence from transition economies. Journal of World Business, 56(1), 101150. https://doi.org/10.1016/j.jwb.2020.101150

Baklanova, O., Petrova, M., \& Koval, V. (2020). Institutional transmission in economic development. Economic Studies, 29(1), 68-91.

Bašić, M., Vlajčić, D., \& Novak, I. (2018). Internationalisation modes in the Australian telecommunications industry: The influence of different innovation types. International Journal of Business and Globalisation, 20(1), 96-119. https://doi.org/10.1504/IJBG.2018.088670

Bašić, M., Gaćina, M., \& Blažević, I. (2020). Factors influencing online and in-store purchase of telecommunications services and equipment in Croatia. International Journal of Contemporary Business and Entrepreneurship, 1(2), 1-12. https://doi.org/10.47954/ijcbe.1.2.1

Bloom, N., Van Reenen, J., \& Williams, H. (2019). A toolkit of policies to promote innovation. Journal of Economic Perspectives, 33(3), 163-184. https://doi.org/10.1257/jep.33.3.163

Brlić, V., Zuric-Hudek, V., Buzolic, L., Rozic, N., \& Begusic, D. (2000). The Croatian telecommunications way toward the communications era. IEEE Communications Magazine, 38(2), 98-106. https://doi.org/10.1109/35.819902

Bryl, L. (2020). Intangible assets in the process of internationalisation. International Journal of Management and Economic, 56(1), 63-78. https://doi.org/10.2478/ijme-2020-0004

Busenitz, L. W., Gomez, C., \& Spencer, J. W. (2000). Country institutional profiles: Unlocking entrepreneurial phenomena. Academy of Management Journal, 43(5), 994-1003. https://doi.org/10.2307/1556423

Chang, S. J., Van Witteloostuijn, A., \& Eden, L. (2010). From the editors: Common method variance in international business research. Journal of International Business Studies, 41, 178-184. https://doi.org/10.1057/jibs.2009.88

Chen, J., Yin, X., \& Mei, L. (2018). Holistic innovation: An emerging innovation paradigm. International Journal of Innovation Studies, 2(1), 1-13. https://doi.org/10.1016/j.jis.2018.02.001

Chesbrough, H. (2004). Managing open innovation. Research-Technology Management, 47(1), 23-26. https://doi.org/10.1080/08956308.2004.11671604

Chesbrough, H. (2006). Open business models: How to thrive in the new innovation landscape. Harvard Business School Press.

Chesbrough, H. (2011). Open services innovation: Rethinking your business to grow and compete in the new era. Jossey-Bass.

Chiaroni, D., Chiesa, V., \& Frattini, F. (2010). Unravelling the process from closed to open innovation: Evidence from mature, asset-intensive industries. $R \& D$ Management, 4O(3), 222-245. https://doi.org/10.1111/j.1467-9310.2010.00589.x

Coviello, N. E., Brodie, R. J., \& Munro, H. J. (2000). An investigation of marketing practice by firm size. Journal of Business Venturing, 15(5-6), 523-545. https://doi.org/10.1016/S08839026(98)00035-4 
Curwen, P., \& Whalley, J. (2007). Tele2 and the strategic role of virtual operations. Information Policy, 9(4), 55-69. https://doi.org/10.1108/14636690710762138

Dahlander, L., \& Gann, D. M. (2010). How open is innovation? Research Policy, 39, 699-709. https://doi.org/10.1016/j.respol.2010.01.013

De Luca, L. M., \& Atuahene-Gima, K. (2007). Market knowledge dimensions and cross-functional collaboration: Examining the different routes to product innovation performance. Journal of Marketing, 71(1), 95-112. https://doi.org/10.1509/jmkg.71.1.095

Denicolai, S., Zucchella, A., \& Strange, R. (2014). Knowledge assets and firm international performance. International Business Review, 23(1), 55-62. https://doi.org/10.1016/j.ibusrev.2013.08.004

Doblinger, C., Dowling, M., \& Helm, R. (2013). Does public policy stimulate firm entrepreneurial behavior and innovative activities? Academy of Management Proceedings, 2013(1), 12184.

Edquist, C., \& Johnson, B. (2000). Institutions and organisations in systems of innovation. In C. Edquist \& M. McKelvey (Eds.), Systems of innovation: Growth, competitiveness and employment (165187). Edward Elgar.

Eisenhardt, K. M. (1989). Building theories from case study research. The Academy of Management Review, 14(4), 532-550. https://doi.org/258557

Erramilli, M. K. (1990). Entry mode choice in service industries. International Marketing Review, 7(5). https://doi.org/10.1108/EUM0000000001535

EC (European Commission). (2010). Internationalisation of European SMEs. Entrepreneurship Unit, Directorate-General for Enterprise and Industry. European Commission.

Fabel, M., Jüttner, F., \& Tybus, M. (2018). Omni-channel demystified: Why retail is (still) the king of telecoms channel mix and why the shift to digital has stalled [online]. atkearney.de. https://www.atkearney.de/documents/1117166/1815509/2018_OmniChannel+demystified.pdf/92b360ff-7267-175f-c1b5-a99604e00e8b

Fong-Reynoso, C., \& Ocampo-Figueroa, L. E. (2010). Intangible resources as a determinant of accelerated internationalisation. Global Journal of Business Research, 4(4), 95-105.

Grönroos, C. (1999). Internationalisation strategies for services. Journal of Services Marketing, 13(4/5), 290-297. https://doi.org/10.1108/08876049910282547

Hair, J. F., Sarstedt, M., Ringle, C. M., \& Gudergan, S. P. (2018). Advanced issues in partial least squares structural equation modeling (PLS-SEM). Sage.

Huang, T.-T., Chen, L., \& Stewart, R. A. (2010). The moderating effect of knowledge sharing on the relationship between manufacturing activities and business performance. Knowledge Management Research \& Practice, 8(4), 285-306. https://doi.org/10.1057/kmrp.2010.21

Huang, H. C., Lai, M. C., Lin, L. H., \& Chen, C. T. (2013). Overcoming organisational inertia to strengthen business model innovation: An open innovation perspective. Journal of Organizational Change Management, 26(6), 977-1002. https://doi.org/10.1108/JOCM-04-2012-0047

Hung, K. P., \& Chou, C. (2013). The impact of open innovation on firm performance: The moderating effects of internal R\&D and environmental turbulence. Technovation, 33(10-11), 368-380. https://doi.org/10.1016/j.technovation.2013.06.006

Huurdeman, A. A. (2003). The worldwide history of telecommunications. John Wiley \& Sons.

Johnson, M. W., Clayton, M., Christensen, C. M., \& Kagermann, H. (2008). Reinventing your business model. Harvard Business Review, 86(12). https://hbr.org/2008/12/reinventing-your-businessmodel 
Kalinic, I., \& Clegg, J. (2017). SME internationalisation, public policy and the growth agenda. In K. Ibeh, P.E. Tolentino, O.E.M. Janne, \& X.Liu (Eds.), Growth frontiers in international business (33-46). Palgrave Macmillan. https://doi.org/10.1007/978-3-319-48851-6_3

Kyläheiko, K., Jantunen, A., Puumalainen, K., Saarenketo, S., \& Tuppura, A. (2011). Innovation and internationalisation as growth strategies: The role of technological capabilities and appropriability. International Business Review, 20(5), 508-520. https://doi.org/10.1016/j.ibusrev.2010.09.004

Laffont, J. J., \& Tirole, J. (2001). Competition in telecommunications. MIT press.

Lakhani, K. R., Hila L.-A., \& Tushman. M. (2013). Open innovation and organisational boundaries: Task decomposition, knowledge distribution and the locus of innovation. In A. Grandori (Ed.), Handbook of economic organisation: Integrating economic and organisation theory (355-382). Edward Elgar Publishing.

Langerak, F., Jan Hultink, E., \& Robben, H. S. (2004). The role of predevelopment activities in the relationship between market orientation and performance. R\&D Management, 34(3), 295-309. https://doi.org/10.1111/j.1467-9310.2004.00340.x

Mikl-Horke, G. (2004). Globalisation, transformation and the diffusion of management innovations. Journal for East European Management Studies, 9(2), 98-122. https://doi.org/10.5771/09496181-2004-2-98

Miocević, D., \& Crnjak-Karanovic, B. (2010). New realities of the SME internationalisation: A capability perspective. Economic research - Ekonomska istraživanja, 23(3), 43-56. https://doi.org/10.1080/1331677X.2010.11517422

Moore, G. A. (2004). Darwin and the demon: Innovating within established enterprises. Harvard Business Review, 82(7-8), 86-92. https://hbr.org/2004/07/darwin-and-the-demon-innovating-withinestablished-enterprises

Mortara, L., \& Minshall, T. (2011). How do large multinational firms implement open innovation? Technovation, 31(10-11), 586-597. https://doi.org/10.1016/j.technovation.2011.05.002

Nefat, A., Belazić, D., \& Alerić, D. (2012). Antecedents and outcomes of service recovery satisfaction in telecommunications in Croatia along with the role of image and perceived switching costs. Economic research - Ekonomska istraživanja, 25(4), 1051-1066. https://doi.org/10.1080/1331677X.2012.11517547

Nelson, R. R., \& Nelson, K. (2002). Technology, institutions, and innovation systems. Research Policy, 31(2), 265-272. https://doi.org/10.1016/S0048-7333(01)00140-8

Noam, E. (1992). Telecommunications in Europe. Oxford University Press.

Nyuur, R. B., Ofori, D. F., \& Debrah, Y. A. (2016). The impact of FDI inflow on domestic firms' uptake of CSR activities: The moderating effects of host institutions. Thunderbird International Business Review, 58(2), 147-159. https://doi.org/10.1002/tie.21744

Oviatt, B. M., \& McDougall, P. P. (1995). Global start-ups: Entrepreneurs on a worldwide stage. Academy of Management Perspectives, 9(2), 30-43. https://doi.org/10.5465/ame.1995.9506273269

Parida, V., Westerberg, M., \& Frishammar, J. (2012). Inbound open innovation activities in high-tech SMEs: The impact on innovation performance. Journal of Small Business Management, 50(2), 283-309. https://doi.org/10.1111/j.1540-627X.2012.00354.x

Peng, M. W., \& Luo, Y. (2000). Managerial ties and firm performance in a transition economy: The nature of a micro-macro link. Academy of Management Journal, 43(3), 486-501. https://doi.org/10.2307/1556406 
Podsakoff, P. M., \& Organ, D. W. (1986). Self-reports in organisational research: Problems and $\begin{array}{llll}\text { prospects. Journal of } & \text { 531-544. }\end{array}$ https://doi.org/10.1177/014920638601200408

Radas, S., \& Bozic, L. (2009). The antecedents of SME innovativeness in an emerging transition economy. Technovation, 29(6-7), 438-450. https://doi.org/10.1016/j.technovation.2008.12.002

Rangus, K., Drnovšek, M., Di Minin, A., \& Spithoven, A. (2017). The role of open innovation and absorptive capacity in innovation performance: Empirical evidence from Slovenia. Journal of East European Management Studies, 22(1), 39-62. https://doi.org/10.5771/0949-6181-2017-1-39

Roy, P., \& Yami, S. (2009). Managing strategic innovation through coopetition. International Journal of Entrepreneurship and Small Business, 8(1), 61-73. https://doi.org/10.1504/IJESB.2009.024105

Saarenketo, S., Puumalainen, K., Kyläheiko, K., \& Kuivalainen, O. (2008). Linking knowledge and internationalisation in small and medium-sized enterprises in the ICT sector. Technovation, 28(9), 591-601. https://doi.org/10.1016/j.technovation.2007.12.003

Sabolić, D. (2009). Telecommunications reform in Croatia. Technology in Society, 31(1), 100-110. 10.1016/j.techsoc.2008.10.005

Sheng, S., Zhou, K. Z., \& Li, J. J. (2011). The effects of business and political ties on firm performance: Evidence from China. Journal of Marketing, 75(1), 1-15. https://doi.org/10.1509/jm.75.1.1

Sisodiya, S. R., Johnson, J. L., \& Gregoire, Y. (2013). Inbound open innovation for enhanced performance: Enablers and opportunities. Industrial Marketing Management, 42(5), 836-849. https://doi.org/10.1016/j.indmarman.2013.02.018

Stojčić, N. (2021). Collaborative innovation in emerging innovation systems: Evidence from Central and Eastern Europe. The Journal of Technology Transfer, 46(2), 531-562. https://doi.org/10.1007/s10961-020-09792-8

Svetličič, M., Jaklič, A., \& Burger, A. (2007). Internationalisation of small and medium-size enterprises from selected Central European Economies. Eastern European Economics, 45(4), 36-65. https://doi.org/10.2753/EEE0012-8775450402

Tomizawa, A., Zhao, L., Bassellier, G., \& Ahlstrom, D. (2020). Economic growth, innovation, institutions, and the Great Enrichment. Asia Pacific Journal of Management, 37(1), 7-31. https://doi.org/10.1007/s10490-019-09648-2

Vuković, A. J., Gagić, S., Terzić, A., Petrović, M. D., \& Radovanović, M. (2018). The impact of organisational learning on innovation: Case study of the Serbian hotel industry. Journal of East European Management Studies, 23(4), 673-692. https://doi.org/10.5771/0949-6181-2018-4-673

West, J., Salter, A., Vanhaverbeke, W., \& Chesbrough, H. (2014). Open innovation: The next decade. Research Policy Special Issue Articles - Open Innovation: New insights and evidence, 43(5), 805-811. https://doi.org/10.1016/j.respol.2014.03.001

Wright, M., Westhead, P., \& Ucbasaran, D. (2007). Internationalisation of small and medium-sized enterprises (SMEs) and international entrepreneurship: A critique and policy implications. Regional Studies, 41(7), 1013-1030. https://doi.org/10.1080/00343400601120288

Xiao, S. S., Lew, Y. K., \& Park, B. I. (2019). '2R-based view' on the internationalisation of service MNEs from emerging economies: Evidence from China. Management International Review, 59(4), 643673.

Yin, R. (1984). Case study research. Sage Publications.

Zahra, S. A., \& George, G. (2002). Absorptive capacity: A review, reconceptualisation, and extension. Academy of Management Review, 27(2), 185-203. https://doi.org/10.2307/4134351 
Zakery, A., \& Saremi, M. S. (2020). Knowledge and intellectual capital in internationalising SMEs, case study in technology-based health companies. Journal of Intellectual Capital, 22(2), 219-242. https://doi.org/10.1108/JIC-02-2020-0048

Zhu, Y., Wittmann, X., \& Peng, M. W. (2012). Institution-based barriers to innovation in SMEs in China. Asia Pacific Journal of Management, 29(4), 1131-1142. https://doi.org/10.1007/s10490-0119263-7

The research article has been reviewed. | Received: August 23, 2021; Revised: October 27, 2021; Accepted: December 10, 2021; Pre-published online: February 23, 2022; Published in the regular issue: September 19, 2022. 